Thorax (1968), 23, 421 .

\title{
Effects of inhalation of an artificial fog
}

\author{
J OH N D. A B E R N E T H Y ${ }^{1}$ \\ From the M.R.C. Pneumoconiosis Research Unit, Llandough Hospital, Penarth, Glamorgan
}

\begin{abstract}
Atmospheric fog plays some role in the production of symptoms in chronic bronchitis, but hitherto the blame has rested with pollutants rather than with the water droplet content itself. An investigation of the effects of an artificial water-containing fog at room temperature on the F.E.V.$_{1 \cdot 0}$ of seven patients with chronic bronchitis showed a significant reduction (mean $17.9 \%$ ) as compared with a minimal or absent effect in seven out of eight normal subjects. The effect tended to persist in sensitive subjects but could be reversed by a bronchodilator. Additional experiments measuring airways resistance, total pulmonary resistance, and static and dynamic compliance tended to support the hypothesis that the fog effect is due to refiex bronchoconstriction. I suggest that water droplets, each having a finite momentum, initiate the reflex in the same manner as dust particles. Although these experiments were confined to large doses inhaled for brief intervals, it is possible that the presence of water droplets alone would increase the morbidity from atmospheric fog. Epidemiological studies on the effects of fog should include direct measurement of the water droplet content. Therapeutic aerosols might also produce this adverse effect.
\end{abstract}

Many patients with chronic chest disease complain of aggravation of their symptoms of breathlessness caused by atmospheric fog and mist. Furthermore, personal experience in London during the severe fog of December 1962 indicated that many of these patients became acutely wheezy within hours of the onset of the fog. The factors thought to contribute to such dramatic episodes occurring in London have been studied by Boyd (1960) by means of bronchitis mortality figures. He found the strongest correlation of mortality with temperature and absolute humidity (both negatively correlated) followed by sulphur dioxide and smoke levels, in that order (both positively correlated), and little or no correlation with visibility. In fact, the influence of $\mathrm{SO}_{2}$ and smoke was limited mainly to temperatures below $0^{\circ} \mathrm{C}$.

Nevertheless, the rapid onset and short latency of exacerbations of bronchitis under foggy conditions suggest a direct physicochemical action of some component of fog on the respiratory tract. The roles of $\mathrm{SO}_{2}$ and of smoke have received considerable attention in this respect to the exclusion of the possible effects of the water droplet cloud itself. This paper, therefore, is concerned with the effect of a pure water-containing fog on normal subjects and on patients with chronic chest disease, as assessed chiefly by the F.E.V.1.0.

1 Present address: Center for Theoretical Biology, State University of New York at Buffalo. Buffalo, New York

\section{METHODS}

The fog was prepared from distilled water according to the method of McKerrow (1959). A stream of air cooled to approximately $-20^{\circ} \mathrm{C}$. is passed into a mixing chamber (a polyethylene bag) into which is injected a stream of steam. As a result, a visible cloud of fine water droplets is formed.

In order to eliminate the known effects of cold air per se on the subject (Wells, Walker, and Hickler, 1960), the mixture was passed through a heat exchanger to bring the temperature up to ambient levels $\left(23^{\circ}-25^{\circ}\right.$ C. $)$. All experiments were performed under standard conditions of air flow $(30 \mathrm{l} . / \mathrm{min}$.) and steam input, so that a reasonably constant density of fog, as judged by eye, was obtained. The total water content of the mixture, measured by the change of weight imparted to a drying agent (silica gel) by a known volume of fog, lay between 10 and $20 \mathrm{mg}$./ litre. As the absorption of water vapour was not taken into account these figures would overestimate the true content of water in droplet form. Attempts to estimate particle size were not successful because of difficulty in obtaining an image of the droplets on a glass slide.

The age and sex of subjects for the experiment described here are shown in Table I. There were both normal and abnormal subjects, some of whom participated in more than one of the three types of experiment. Apart from certain criteria described below for selecting the abnormal subjects, the factor that determined a possible subject's selection for a particular experiment was his availability at that time. 
T A B L E I

\begin{tabular}{|c|c|c|c|c|c|c|c|}
\hline \multicolumn{3}{|c|}{ Normal Subjects } & \multicolumn{5}{|c|}{ Patients } \\
\hline Subject & Age & Sex & Subject & Age & $\operatorname{Sex}$ & $\begin{array}{l}\text { Chronic } \\
\text { Bron- } \\
\text { chitis }\end{array}$ & $\begin{array}{c}\text { Simple } \\
\text { Pneumo- } \\
\text { coniosis } \\
\text { Category }\end{array}$ \\
\hline $\begin{array}{ll}\mathbf{N} & 1 \\
\mathbf{N} & \mathbf{2} \\
\mathbf{N} & \mathbf{3} \\
\mathbf{N} & \mathbf{4} \\
\mathbf{N} & \mathbf{5} \\
\mathbf{N} & \mathbf{6} \\
\mathbf{N} & 7 \\
\mathbf{N} & 8 \\
\mathbf{N} & \mathbf{9} \\
\mathbf{N} 10 \\
\mathbf{N} 11 \\
\mathbf{N} 12 \\
\mathbf{N}^{1}\end{array}$ & $\begin{array}{l}51 \\
54 \\
21 \\
41 \\
29 \\
49 \\
32 \\
29 \\
29 \\
32 \\
33 \\
25 \\
21\end{array}$ & $\begin{array}{l}\mathbf{M} \\
\mathbf{M} \\
\mathbf{F} \\
\mathbf{M} \\
\mathbf{M} \\
\mathbf{M} \\
\mathbf{M} \\
\mathbf{M} \\
\mathbf{M} \\
\mathbf{M} \\
\mathbf{M} \\
\mathbf{M} \\
\mathbf{M}\end{array}$ & $\begin{array}{ll}P & 1 \\
P & 2 \\
P & 3 \\
P & 4 \\
P & 5 \\
P & 6 \\
P & 7 \\
P & 8 \\
P & 9 \\
P 10 \\
P 11 \\
P 12 \\
P 13 \\
P 14 \\
P 15 \\
P 15 \\
P 16 \\
\text { P17 }\end{array}$ & $\begin{array}{l}66 \\
66 \\
64 \\
61 \\
64 \\
68 \\
59 \\
64 \\
53 \\
62 \\
56 \\
63 \\
59 \\
65 \\
56 \\
71 \\
54\end{array}$ & $\begin{array}{l}\mathbf{M} \\
\mathbf{M} \\
\mathbf{M} \\
\mathbf{M} \\
\mathbf{M} \\
\mathbf{M} \\
\mathbf{M} \\
\mathbf{M} \\
\mathbf{M} \\
\mathbf{M} \\
\mathbf{M} \\
\mathbf{M} \\
\mathbf{M} \\
\mathbf{M} \\
\mathbf{M} \\
\mathbf{M} \\
\mathbf{M}\end{array}$ & $\begin{array}{l}\mathbf{X} \\
\mathbf{X} \\
\mathbf{X} \\
\mathbf{X} \\
\mathbf{X} \\
\mathbf{X} \\
\mathbf{X} \\
\mathbf{X} \\
\mathbf{X} \\
\mathbf{X} \\
\mathbf{X} \\
\mathbf{X} \\
\mathbf{X} \\
\mathbf{X} \\
\mathbf{X} \\
\mathbf{X} \\
\mathbf{X}\end{array}$ & $\begin{array}{l}0 \\
1 \\
1 \\
3 \\
2 \\
0 \\
3 \\
1 \\
0 \\
2 \\
3 \\
0 \\
3 \\
1 \\
0 \\
3 \\
2\end{array}$ \\
\hline
\end{tabular}

${ }^{1}$ Subject $\mathrm{N}$ suffered from mild bronchial asthma.

2 No history of dust exposure.

The patients were chosen from a group of inpatient ex-miners who had chronic bronchitis defined as cough and sputum with periods of chest illness. Almost all had a history of some exposure to coal dust, with radiological categories ranging from 0 to 3 simple pneumoconiosis (Table I). There were miscellaneous reasons for admission, respiratory illnesses predominating. Experiments were performed late in convalescence. Cases of chronic bronchitis uncomplicated by pneumoconiosis would have been preferable, but since the work was conducted in a Pneumoconiosis Research Unit the only patients available were miners with pneumoconiosis. To the extent that simple pneumoconiosis appears to play but a minor role in the symptomatology of these patients, the choice seems justifiable. The normal controls were healthy laboratory workers and, as can be seen from Table I, tended to be younger. Subject N, a laboratory worker, was excluded from each of the above classes because of mild asthma precipitated by upper respiratory infections, but the relevant data have been included merely to amplify some features of the response to fog observed in a number of the other subjects.

The effect of fog on the F.E.V.1.0 was measured in the following manner. The seated subject inhaled the fog through a mouthpiece, the expired air and excess fog escaping via an expiratory valve. The inhalation period in early experiments was 10 minutes, but this was progressively reduced to 3 minutes as it became apparent that the major portion of any effect occurred during this interval.

The F.E.V.1.0 was measured immediately before and after the inhalation, the standard procedure being to take five readings, the first two being discarded and the mean being obtained from the remainder.

The possible effects on the F.E.V.1.0 of the experimental situation as distinct from the effects, if any, of fog itself were assessed in two ways. In the normal subjects a blank experiment, i.e., breathing air from $\stackrel{\overrightarrow{\bar{S}}}{\stackrel{\overrightarrow{0}}{(}}$ the apparatus instead of fog, was performed several $\frac{}{0}$ weeks after the fog experiment. In eight patients, on $\frac{}{0}$ the other hand, two Latin square trials were arranged $\overline{\frac{\sigma}{5}}$ so that four patients received four different 'treat- $\widehat{\otimes}$ ments' at four times on the same day. The treatments, $\triangle$ each of which was delivered to the patient through क the apparatus, were $(a)$ fog, $(b)$ compressed air, (c) air $\vec{\circ}$ moistened with steam, and $(d)$ cold air $\left(5^{\circ} \mathrm{C}\right.$.). The interval between treatments was two to three hours. $\vec{\omega}$

Airways resistance (A.W.R.) was measured in some $\mathscr{\sigma}$ normal subjects before and after fog in a second $\overrightarrow{\vec{x}}$ series of experiments by means of the body $x$ plethysmograph (DuBois, Botelho, and Comroe, 1956). The recorded A.W.R. was the mean of five consecutive measurements.

In a third series, using both normal and abnormal subjects, static compliance, dynamic compliance, and 을 pulmonary flow resistance were measured before and after fog by using an oesophageal balloon to estimate $c$ transpulmonary pressure and a spirometer to measure $\rightleftharpoons$ volume changes. For measuring static compliance an $\vec{\oplus}$ interrupter valve proximal to the spirometer gave the pressure at zero flow, and from a pressure-volume plot of the full range of, for example, inspiration the slope of the central linear portion of the curve furnished the inspiratory compliance. Expiratory compliance was obtained similarly, the recorded value being the mean of three 'runs' in each case. For the $\frac{\circ}{\varnothing}$ other measurements the subject was asked to breathe $\varrho$ quietly at some fixed mean level close to functional $\overrightarrow{\overrightarrow{0}}$ residual capacity. The pressure-volume relationships 3 at the maxima and minima of the volume trace yielded the dynamic inspiratory and expiratory compliance respectively. Pulmonary resistance was calculated from the slope of the volume trace, i.e., the flow, 을 and pressure at mid-tidal volume. The values recorded for pulmonary resistance and dynamic compliance were the means of 10 consecutive respiratory cycles.

No attempt was made to exclude possible psychological influences of fog breathing because of the difficulty in disguising this mixture. However, care was taken to avoid suggesting that a particular effect $ㅇ$ might accrue from the inhalation.

\section{RESULTS}

In Table II are shown the changes in the F.E.V ${ }_{\cdot \cdot \cdot \cdot 0}$ N of normal subjects after breathing air (through $\mathrm{\omega}$ the apparatus) and after breathing fog. On average, fog produced a slight reduction of F.E.V ${ }_{\cdot 1 \cdot 0}$, but this change was not significant when $\stackrel{\mathbb{f}}{\oplus}$ compared with the results of the control experiment. Only one subject (N6) showed a considerable fall $(22 \%)$ after fog. This man was in his late $\mathbb{\mathbb { D }}$ forties and, although a moderate smoker, gave no $\frac{?}{\mathbb{Q}}$ history suggestive of chronic bronchitis.

The effects of fog on the F.E.V. $\cdot_{1 \cdot 0}$ in the seven? patients of the first series of experiments are 8 
T A B L E I I

EFFECT OF AIR OR FOG ON THE F.E.V.1.0 OF NORMAL SUBJECTS

\begin{tabular}{|c|c|c|c|c|c|c|}
\hline \multirow{2}{*}{$\begin{array}{c}\text { Subject } \\
\text { N1 } \\
\text { N2 } \\
\text { N3 } \\
\text { N4 } \\
\text { N5 } \\
\text { N6 } \\
\text { N7 } \\
\text { N8 }\end{array}$} & \multirow{2}{*}{$\begin{array}{c}\text { F.E.V.1.0 } \\
\text { (1.) }\end{array}$} & \multicolumn{2}{|c|}{$\underset{(1 .)}{\text { Change on Air }}(\%)$} & \multicolumn{2}{|c|}{$\underset{(1 .)}{\text { Change on Fog }}\left(\begin{array}{l}(\%) \\
\text { Fog }\end{array}\right.$} & \multirow{2}{*}{$\begin{array}{c}\begin{array}{c}\text { Exposure } \\
\text { Time } \\
\text { (min.) }\end{array} \\
3 \\
3 \\
10 \\
10 \\
10 \\
10 \\
10 \\
5\end{array}$} \\
\hline & & $\begin{array}{r}+0.08 \\
-0.04 \\
-0.06 \\
+0.06 \\
-0.17 \\
+0.10 \\
+0.10 \\
+0.14\end{array}$ & $\begin{array}{l}+2.04 \\
-1.34 \\
-1.46 \\
+1.33 \\
-4.43 \\
+2.70 \\
+2.59 \\
+2.87\end{array}$ & $\begin{array}{l}-0.08 \\
-0.16 \\
+0.01 \\
-0.06 \\
-0.12 \\
-0.86 \\
-0.03 \\
+0.38\end{array}$ & $\begin{array}{r}-2.04 \\
-5.35 \\
+0.24 \\
-1.33 \\
-3.12 \\
-23.18 \\
-0.78 \\
+7.80\end{array}$ & \\
\hline Mea & & $\begin{array}{r}+0.02 \\
\text { (S.E. }\end{array}$ & $\begin{array}{l}+0.54^{1} \\
0.94)\end{array}$ & $\begin{array}{c}-0 \cdot 11 \\
\text { (S.E. }\end{array}$ & $\begin{array}{l}{ }^{-3.47^{1}} \\
\pm 3 \cdot 12)\end{array}$ & \\
\hline
\end{tabular}

${ }^{1}$ Difference not significant at $5 \%$ level.

shown in Table III. By contrast with the normal subjects there was a fall in every case, being at least $20 \%$ in four out of seven. The mean age of this group was 64 years, as compared to 38.2 for the normal subjects.

The results of an additional group of seven patients of the same type as those in Table I were

T A B L E I I I

EFFECT OF FOG ON THE F.E.V.1.0 OF PATIENTS

\begin{tabular}{|c|c|c|c|c|}
\hline Subject & $\underset{\text { (i.) }}{\text { F.E.V.1.0 }}$ & \multicolumn{2}{|c|}{$\begin{array}{l}\text { Change on Fog } \\
\text { (1.) }(\%)\end{array}$} & $\begin{array}{c}\text { Exposure } \\
\text { Time } \\
\text { (min.) }\end{array}$ \\
\hline $\begin{array}{l}\text { P1 } \\
\text { P2 } \\
\text { P3 } \\
\text { P4 } \\
\text { P5 } \\
\text { P6 } \\
\text { P7 }\end{array}$ & $\begin{array}{l}0.73 \\
0.79 \\
1.02 \\
1.22 \\
1.40 \\
2.04 \\
0.93\end{array}$ & $\begin{array}{l}-0.19 \\
-0.16 \\
-0.05 \\
-0.17 \\
-0.13 \\
-0.42 \\
-0.28\end{array}$ & $\begin{array}{r}-26.03 \\
-20.25 \\
-4.90 \\
-13.93 \\
-9 \cdot 29 \\
-20.59 \\
-30 \cdot 11\end{array}$ & $\begin{array}{l}5 \\
5 \\
3 \\
3 \\
5 \\
5 \\
5\end{array}$ \\
\hline Mean & & $\begin{array}{r}-0.20 \\
(S\end{array}$ & $\begin{array}{l}-17 \cdot 9 \\
3 \cdot 39)\end{array}$ & \\
\hline
\end{tabular}

excluded from Table III because the experimental conditions differed from those of the control series (e.g., fog temperature different from ambient temperature). Six of these showed a distinct fall in F.E.V.1.0 after fog.

In Table IV is seen the analysis of variance of the post-treatment F.E.V $\cdot_{1 \cdot 0}$ from one Latin square trial, the results from the other being essentially similar. The between-treatment variance was

\section{T A B L E I V}

PATIENTS: ANALYSIS OF VARIANCE (LATIN SQUARE

\begin{tabular}{|c|c|c|c|c|c|}
\hline & D.F. & $\begin{array}{l}\text { Sums of } \\
\text { Squares }\end{array}$ & Variance & $\mathbf{F}$ & $\mathbf{P}$ \\
\hline $\begin{array}{l}\text { Patients } \\
\text { Times of day } \\
\text { Treatments } \\
\text { Residual }\end{array}$ & $\begin{array}{l}3 \\
3 \\
3 \\
6\end{array}$ & $\begin{array}{l}7 \cdot 3475 \\
0.0463 \\
0.1985 \\
0.0823\end{array}$ & $\begin{array}{l}2.4492 \\
0.0154 \\
0.0662 \\
0.0137\end{array}$ & $\begin{array}{r}178.26 \\
1.0154 \\
4.8152\end{array}$ & $\begin{array}{l}<0.001 \\
>0.1 \\
<0.05\end{array}$ \\
\hline
\end{tabular}

significantly larger than would be expected if no treatment had any effect on the F.E.V..$_{\cdot \cdot \cdot 0}$ In addition, the between-patient variance was high, but this is merely an expression of the fact that different patients have different F.E.V ${ }_{\cdot 1 \cdot 0}$ results. It can be seen from Fig. 1, which shows the effect of each treatment on the mean F.E.V.$_{1 \cdot 0}$, that the principal cause of the increased treatment variance was a lowering of the F.E.V $\cdot_{\cdot 1 \cdot 0}$ after fog. The difference between the F.E.V..$_{1 \cdot 0}$ after this

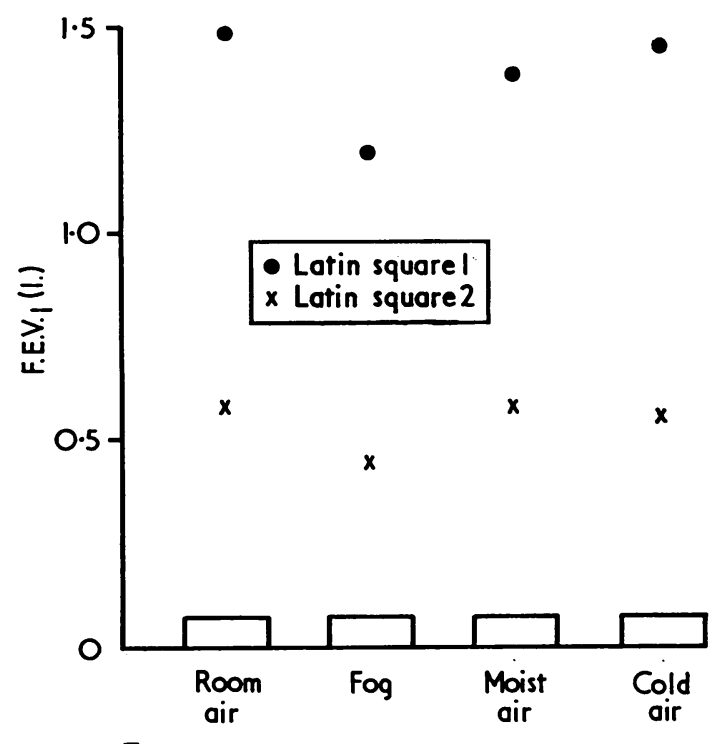

Treatment

FIG. 1. F.E.V.1.0 (mean of four subjects) recorded after each of four treatments in two Latin square trials. Subjects in square 1 were $P 10, P 11, P 12$, and $P 13$; in square $2, P 14$, $P 15, P 16$, and $P 17$.

treatment and after each of the others was significant at the $5 \%$ level in each trial. The systematic difference in F.E.V $\cdot_{\cdot 1 \cdot 0}$ between square 1 and square 2 shown in Fig. 1 was not significant, it being merely another manifestation of the high between-patient variance.

Subject $\mathbf{N}$ also responded to fog with a fall in F.E.V..$_{1 \cdot 0}$ of $20 \%$.

Other effects of fog inhalation noted were a distinct tendency to cough, often after the first breath, which was seen in normal subjects as well as in bronchitics. Most of the patients noticed an increase of wheeziness or 'tightness' within a minute of the start of the inhalation.

That the duration of the effect in a sensitive subject can be substantial is seen in Fig. 2, where subject $\mathbf{N}$ exhibited significant depression of the 


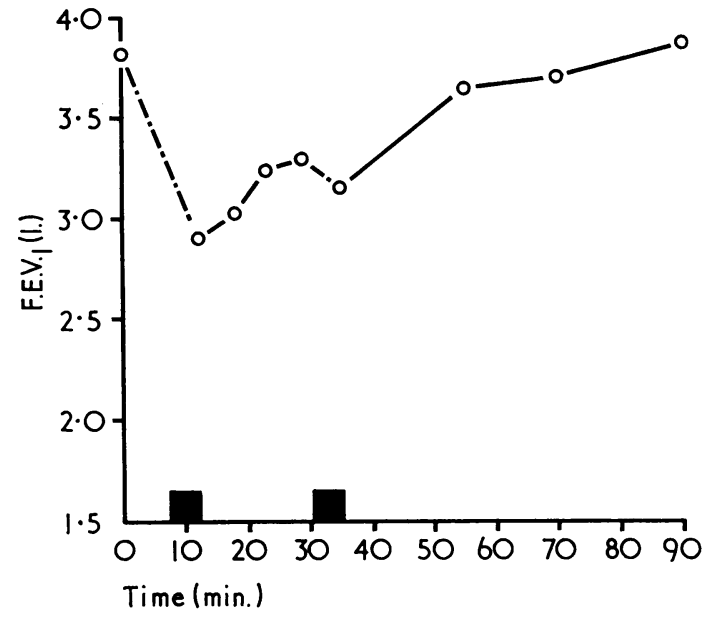

FIG. 2. Serial F.E. $V_{\cdot_{1.0}}$ values in subject $N$, who inhaled two doses of fog at indicated times.

F.E.V. $\cdot 1 \cdot 0$ some 17 minutes after the first of two doses of fog. A similar prolongation of the effect was seen in four patients (Fig. 3). In these subjects inhalation of $\mathrm{Neb}$. Adrenaline et Atropine Co. B.P.C. produced an immediate reversal of the depression of the F.E.V. . $_{1 \cdot(0)}$.

In seven normal subjects A.W.R. measured after fog inhalation for 10-20 minutes showed no significant change except in subject N6 described above, whose A.W.R. increased five-fold from 0.82 to $4.36 \mathrm{~cm}$. $\mathrm{H}_{2} \mathrm{O} / 1$. $/ \mathrm{sec}$. (Table V). In some subjects the sequence of five post-fog measurements (see METHODS) showed an initial increase in A.W.R. followed by a rapid decay to the control level suggestive of a transient effect.

The results for the oesophageal pressurespirometer experiments were as follows (Table VI). In three out of four normal subjects pulmonary flow resistance increased after fog, and in five patients there was a marked increase in one, a slight increase in three, and a slight

T A B L E V

EFFECT OF FOG ON AIRWAYS RESISTANCE

\begin{tabular}{|c|c|c|c|}
\hline \multirow{2}{*}{ Subject } & \multicolumn{2}{|c|}{ A.W.R. (cm. $\left.\mathrm{H}_{2} \mathrm{O} / 1 . / \mathrm{sec}.\right)$} & \multirow{2}{*}{$\begin{array}{c}\text { Exposure } \\
\text { (mine) }\end{array}$} \\
\hline & Before & After & \\
\hline $\begin{array}{ll}N & 3 \\
N & 4 \\
N & 5 \\
N & 6 \\
N & 8 \\
N & 9 \\
N & 10\end{array}$ & $\begin{array}{l}1.14 \\
1.61 \\
0.99 \\
0.82 \\
1.08 \\
1.30 \\
0.72\end{array}$ & $\begin{array}{l}1.14 \\
1.99 \\
1.28 \\
4.36 \\
1.03 \\
1.04 \\
0.80\end{array}$ & $\begin{array}{l}15 \\
10 \\
10 \\
10 \\
20 \\
10 \\
10\end{array}$ \\
\hline Mean & $\begin{array}{c}1.09^{1} \\
(S . E . \pm 0 \cdot 11)\end{array}$ & $\begin{array}{c}1.66^{1} \\
(\text { S.E. } \pm 0.47)\end{array}$ & \\
\hline
\end{tabular}

Difference not significant at $5 \%$ level.

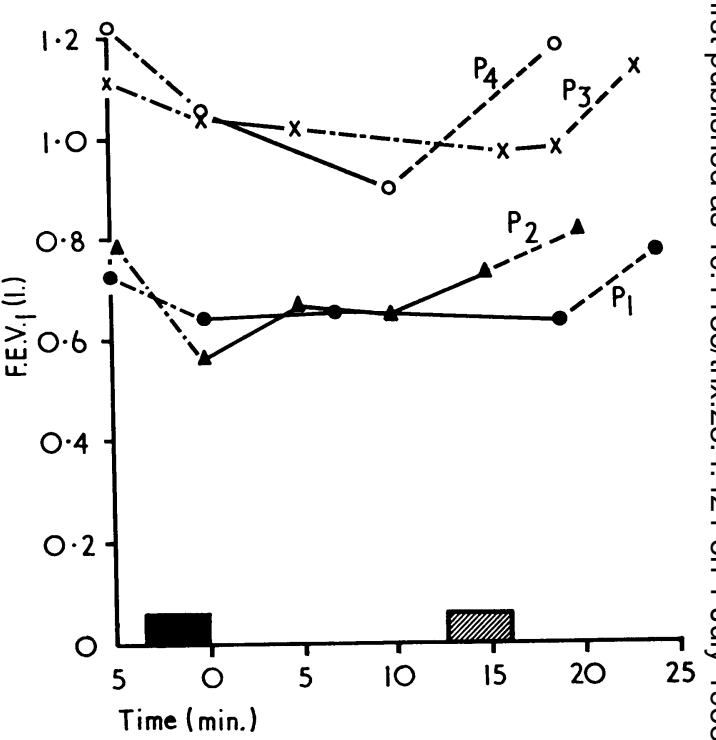

FIG. 3. Serial F.E.V..$_{1 \cdot 0}$ values in four patients showing the duration of the fog effect and the effect of a bronchodilator. Between points connected by .-... subjects inhaled fog for a period indicated by the rectangles on the abscissa. P3 received two doses. Between points connected by $-\ldots-\ldots$ subjects inhaled Neb. Adrenaline et Atropine $\mathbb{Q}$ Co. B.P.C. for four minutes.

decrease in one. Dynamic compliance decreased $\stackrel{\overrightarrow{7}}{\vec{F}}$ appreciably in four out of five patients in contrast to the normal subjects, three of whom showed a slight increase. Also noticeable in these four patients was an increase in the lagging of the volume trace behind the pressure trace. The static 3 . compliance showed no consistent change in either group. Some of the patients were unable to perform the sustained inspiratory or expiratory manœuvres necessary for this measurement. Subject $\mathbf{N}$ showed a marked increase in resistance $\frac{}{O}$ and a decrease in dynamic compliance.

\section{DISCUSSION}

The F.E.V. $\cdot_{1 \cdot 0}$ in our hands gave repeatable results ${ }_{0}^{\infty}$ and showed a decrease after fog in nearly all the patients and in some normal subjects. If one accepts that changes in the F.E.V $\cdot_{1 \cdot 0}$ are due predominantly to variations in the A.W.R., then ${ }_{7}^{+}$ it follows that fog produces directly or by reflex action an increase in A.W.R. The body $\vec{\Phi}$ plethysmograph experiments showed directly that $\frac{}{\Phi}$ subject N6, whose susceptibility had been estab-으 lished by the F.E.V ${ }_{\cdot 1 \cdot 0}$ test, did indeed have $a$ substantial increase in A.W.R. after fog. Addi- 
T A B L E V I

EFFECT OF FOG ON PULMONARY RESISTANCE AND COMPLIANCE

\begin{tabular}{|c|c|c|c|c|c|c|c|}
\hline \multirow{2}{*}{\multicolumn{2}{|c|}{ Subject }} & \multirow{2}{*}{$\begin{array}{c}\text { Total } \\
\text { Pulmonary } \\
\text { Resistance } \\
\text { (cm. } \mathbf{H}_{\mathbf{2}} \mathrm{O} / 1 . / \mathrm{sec} \text {.) } \\
\end{array}$} & \multirow{2}{*}{ Change } & \multicolumn{3}{|c|}{ Compliance $\left(1 . / \mathrm{cm} . \mathrm{H}_{2} \mathrm{O}\right)$} & \multirow{2}{*}{$\begin{array}{c}\text { Exposure } \\
\text { (mime } \\
\text { (min.) }\end{array}$} \\
\hline & & & & $\begin{array}{l}\text { Dynamic } \\
\text { Insp. }\end{array}$ & Insp. & Exp. & \\
\hline $\begin{array}{c}\text { Normal Subjects } \\
\mathbf{N} 3 \text { before } \\
\text { after } .\end{array}$ & $\begin{array}{l}\cdots \\
\cdots\end{array}$ & $\begin{array}{l}0 \cdot 75 \\
1 \cdot 34\end{array}$ & +0.59 & $\begin{array}{l}0 \cdot 127 \\
0 \cdot 134\end{array}$ & $\begin{array}{l}0 \cdot 176 \\
0 \cdot 188\end{array}$ & $\begin{array}{l}0 \cdot 170 \\
0 \cdot 198\end{array}$ & 10 \\
\hline $\begin{array}{c}\text { N } 8 \text { before } \\
\text { after } .\end{array}$ & $\begin{array}{l}\cdots \\
\cdots\end{array}$ & $\begin{array}{l}2 \cdot 18 \\
1.68\end{array}$ & -0.50 & $\begin{array}{l}0.261 \\
0.258\end{array}$ & $\begin{array}{l}0 \cdot 218 \\
0.316\end{array}$ & $\begin{array}{l}0.234 \\
0.233\end{array}$ & 5 \\
\hline $\begin{array}{c}\text { N11 before } \\
\text { after .. }\end{array}$ & $\cdots$ & $\begin{array}{l}1 \cdot 79 \\
4 \cdot 58\end{array}$ & $+2 \cdot 79$ & $\begin{array}{l}0 \cdot 248 \\
0 \cdot 256\end{array}$ & $\begin{array}{l}0 \cdot 229 \\
0.251\end{array}$ & $\begin{array}{l}0 \cdot 278 \\
0 \cdot 282\end{array}$ & 10 \\
\hline $\begin{array}{c}\text { N12 before } \\
\text { after .. }\end{array}$ & $\begin{array}{l}\cdots \\
\cdots\end{array}$ & $\begin{array}{l}0 \cdot 87 \\
2 \cdot 36\end{array}$ & $+1 \cdot 49$ & $\begin{array}{l}0 \cdot 161 \\
0 \cdot 206\end{array}$ & $\begin{array}{l}0 \cdot 186 \\
0 \cdot 152\end{array}$ & $\begin{array}{l}0 \cdot 199 \\
0.229\end{array}$ & 10 \\
\hline Mean change & $\cdots$ & & +1.09 & +0.012 & +0.024 & +0.015 & \\
\hline $\begin{array}{c}\text { Abnormal Subjects } \\
\text { P } 5 \text { before } \\
\text { after . . }\end{array}$ & . & $\begin{array}{l}5 \cdot 65 \\
5 \cdot 78\end{array}$ & $+0 \cdot 13$ & $\begin{array}{l}0 \cdot 105 \\
0 \cdot 077\end{array}$ & $\begin{array}{l}0 \cdot 272 \\
0 \cdot 150\end{array}$ & - & 5 \\
\hline $\begin{array}{c}\text { P } 6 \begin{array}{l}\text { before } \\
\text { after . . }\end{array} \\
\end{array}$ & $\cdots$ & $\begin{array}{l}1.29 \\
1.94\end{array}$ & +0.65 & $\begin{array}{l}0 \cdot 212 \\
0 \cdot 187\end{array}$ & $\begin{array}{l}0 \cdot 209 \\
0 \cdot 235\end{array}$ & $\begin{array}{l}0.318 \\
0.468\end{array}$ & 5 \\
\hline $\begin{array}{c}\text { P } 7 \text { before } \\
\text { after .. }\end{array}$ & $\cdots$ & $\begin{array}{r}9 \cdot 90 \\
16 \cdot 50\end{array}$ & $+6 \cdot 60$ & $\begin{array}{l}0.083 \\
0.054\end{array}$ & $\begin{array}{l}0 \cdot 171 \\
0 \cdot 102\end{array}$ & $\begin{array}{c}0.218 \\
-\end{array}$ & 5 \\
\hline $\begin{array}{c}\text { P } 8 \text { before } \\
\text { after } \ldots\end{array}$ & $\begin{array}{l}\cdots \\
\cdots\end{array}$ & $\begin{array}{l}4 \cdot 39 \\
4 \cdot 58 \\
\end{array}$ & $+0 \cdot 19$ & $\begin{array}{l}0.118 \\
0.043 \\
\end{array}$ & - & - & 3 \\
\hline $\begin{array}{c}\text { P } 9 \text { before } \\
\text { after . . }\end{array}$ & $\cdots$ & $\begin{array}{l}2 \cdot 88 \\
2 \cdot 73\end{array}$ & $-0 \cdot 15$ & $\begin{array}{l}0.209 \\
0.233 \\
\end{array}$ & $\begin{array}{l}0 \cdot 243 \\
0 \cdot 286\end{array}$ & $\begin{array}{l}0.401 \\
0.303\end{array}$ & 5 \\
\hline Mean change & $\cdots$ & & $+2 \cdot 69$ & -0.031 & & & \\
\hline $\begin{array}{l}\text { N before } \\
\text { after ... }\end{array}$ & $\begin{array}{l}\cdots \\
\cdots\end{array}$ & $\begin{array}{r}1 \cdot 60 \\
10 \cdot 30\end{array}$ & $+8 \cdot 70$ & $\begin{array}{l}0 \cdot 125 \\
0 \cdot 100\end{array}$ & $\begin{array}{l}0 \cdot 178 \\
0 \cdot 181\end{array}$ & $\begin{array}{l}0.182 \\
0.192\end{array}$ & 10 \\
\hline
\end{tabular}

tional indirect evidence in support of this is that the effect on the F.E.V ${ }_{\cdot 1 \cdot 0}$ can be reversed by a bronchodilator.

It might have been expected, therefore, that the pulmonary flow resistance would show a welldefined increase in patients after fog instead of the observed somewhat variable response. The reasons for this may have been experimental and/or physiological. (1) In a pilot experiment on a normal subject breathing air, the method produced a considerable scatter of values for the resistance, due possibly to inaccuracies in the graphical method for obtaining flow. (2) According to Otis, McKerrow, Bartlett, Mead, McIlroy, Selverstone, and Radford (1956), subjects with inhomogeneity of mechanical time constants in the lungs can reduce the effective resistance (i.e., pulmonary flow resistance) by increasing the frequency of breathing. This effect might conceivably have masked the increase in A.W.R. due to fog in some of our abnormal subjects since the frequency of breathing was not controlled. (3) A third possibility, albeit unlikely, would be that the fog effect was masked by a decrease in tissue resistance.

The reduction in dynamic compliance and increase in lagging of ventilation behind pressure changes seen in the abnormal subjects after fog is also consistent with the model of Otis $e t a l$. and would be affected by increasing the resistances, and hence the time constants, in an already inhomogeneous lung.

On the basis of the F.E.V..$_{1 \cdot 0}$ results, it appears that fog affects people in two ways: some respond little, if at all (most normal subjects), and some have a marked response (most bronchitics). However, much larger samples would be necessary to distinguish between such a bimodal distribution and a continuous distribution of response to fog. Furthermore, a more rigorous selection of subjects would be required to establish an association between bronchitis and response to fog, since there were differences other than bronchitis between the controls and the abnormal group, such as age and the presence of pneumoconiosis.

A possible mode of action of fog could be a consequence of the additional water (in droplet form) with its high specific heat relative to that of air, causing undue cooling of the respiratory mucosa. However, the increase in heat energy required to raise fog water droplets from, say, $25^{\circ} \mathrm{C}$. to $37^{\circ} \mathrm{C}$. (assuming no vapourization) can be calculated to be $7 \%$ using a value of $20 \mathrm{mg}$. $/ 1$. for fog water droplet content and values for the 
density of air at $0^{\circ} \mathrm{C}$. and the specific heat of air to be $\mathbf{1 . 2 9}$ and $\mathbf{0 . 2 5}$ respectively (Handbook of Chemistry and Physics, 1966). Any vapourization of the water droplets during the warming process would reduce this calculated value. Although such vapourization per se consumes energy, it would not alter the overall energy requirements of humidification, since in this case the water droplets would be complementing the normal supply of water vapour from the respiratory mucosa. On the basis of the above calculation, therefore, it is suggested that the heat requirement of fog for physiological warming and humidification, relative to that of air, is negligible.

How much fog is vapourized, or indeed warmed, before reaching the terminal airways is another question and would depend on the efficiency of the heat exchange mechanism, on the degree of turbulence, and the rate of airflow and temperature gradients under these dynamic conditions, as well as on particle size and stability. Ingelstedt (1956) has established that in normal subjects inspired air is saturated and warmed to within a degree or two of $37^{\circ} \mathrm{C}$. by the time it reaches the larynx. Fog droplets at a temperature lower than that of the mucosa will tend to be resistant to evaporation. It is possible, nevertheless, that under the influence of such an efficient heat exchange system, given the potentially large surface area of fog water droplets, some or all the fog will have been vapourized by the time the lower respiratory tract is reached. This conjecture, however, does not take into account the fact that mouth breathing, as in the fog experiment, might reduce the efficiency of the heat exchange mechanism.

I think that the most likely mode of action of fog water droplets is stimulation of receptors in the respiratory tract in the same manner as dust particles, producing in turn a reflex bronchoconstriction. Indeed, if an appreciable momentum on impact was the adequate stimulus for such receptors then water droplets would be physiologically indistinguishable from foreign particles. Receptors which respond to mechanical stimulation and to dust particles have already been described in man and experimental animals, and there is evidence for their presence in the larynx as well as in the lower respiratory tract (Widdicombe, 1963). The possibility that water droplets may not survive beyond the larynx does not therefore negate such a hypothesis. These receptors may also mediate the cough reflex, according to some workers. One of the most marked effects of fog was coughing, even in normal subjects.
In the light of the previous discussion on heat exchange there exists the alternative that the 0 effective stimulus might be contact between cool 음 water droplets and cold receptors. This is not $\frac{\bar{\sigma}}{\sigma}$ supported by a few experiments (unpublished) on $\mathbb{\mathbb { D }}$ the effect of varying the temperature of the inhalation. Fog at $37^{\circ}$ C. was still effective in $s$ depressing the F.E.V ${ }_{\cdot 1 \cdot 0}$. However, the impression was gained that lowering the temperature $\overrightarrow{\vec{\omega}}$ increased the effectiveness, but the circumstances $\omega^{\circ}$ of fog production were such that this could have $\overrightarrow{\vec{x}}$ been simply an effect of dosage.

The concentrations of fog in these experiments were in excess of that found naturally, i.e., 10 to $20 \mathrm{mg}$./1. as against $1 \mathrm{mg}$./1. or less. While it is not valid to extrapolate to the clinical situation $\mathrm{O}$ from experiments on large doses of fog inhaled for brief intervals, it is possible that the effects $ᄃ$ described in this paper might have to be taken into account in the causation of acute attacks of $\vec{\varphi}$ breathlessness in foggy conditions.

To determine the role of fog water droplets in producing morbidity and mortality under natural conditions would require epidemiological studies in which direct measurements of droplet concentration and size are made. Measurement of $\frac{\Phi}{\Phi}$ absolute humidity (Boyd, 1960) is inadequate in the present context, since it concerns water vapour $\overrightarrow{\overrightarrow{0}}$ pressure only, and says nothing about water 3 droplet content. Measurement of visibility likewise is an inadequate parameter of droplet content, since impairment of visibility is influenced also by the presence of smoke and by particle size.

Finally, the effect of inhalation of a cloud of water droplets on sensitive subjects suggests the need for investigation of such an effect in therapeutic aerosols employing water as if it were a bland carrier.

\section{REFERENCES} Boyd, J. T. (1960). Climate, air pollution, and mortality. Brit. J. O
prev. soc. Med., 14, 123.

DuBois, A. B., Botelho, S. Y., and Comroe, J. H., Jr. (1956). A new N method for measuring airway resistance in man using a body plethysmograph: values in normal subjects and in patients with $N$ respiratory disease. J. clin. Invest., 35, 327.

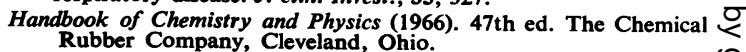

Ingelstedt, S. (1956). Studies on the conditioning of air in the respiratory tract. Acta oto-laryng. (Stockh.), Suppl. 131.

McKerrow, C. B. (1959). A simple method of making a fog. J. Physiol. (Lond.), 147, 38P.

Otis, A. B., McKerrow, C. B., Bartlett, R. A., Mead, J., Mcllroy, M. B., Selverstone, N. J., and Radford, E. P. (1956). Mechanical factors in distribution of pulmonary ventilation. J. appl. Physiol., $8,427$.

Wells, R. E., Walker, J. E. C., and Hickler, R. B. (1960). Effects of $\frac{\mathbb{D}}{\mathbb{Q}}$ cold air on respiratory airfiow resistance in patients with respiratory-tract disease. New Engl. J. Med., 263, 268.

Widdicombe, J. G. (1936). The regulation of tracheobronchial smooth muscle. Physiol. Rev., 43, 1.

\section{\begin{tabular}{l} 
言 \\
\hline
\end{tabular}}

